Title no. 91-S7

\title{
Bond of Epoxy-Coated Reinforcement: Cover, Casting Position, Slump, and Consolidation
}
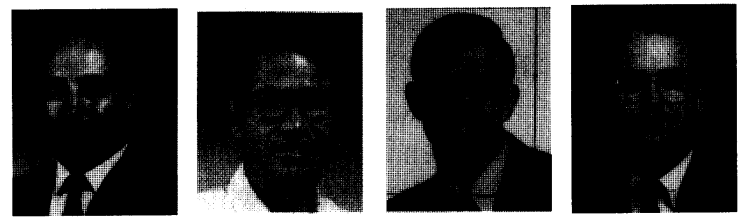

by Hossain Hadje-Ghaffari, Oan Chul Choi, David Darwin, and Steven L. McCabe

The effects of concrete cover, casting position, concrete slump, and degree of consolidation on the reduction in bond strength between reinforcing bars and concrete caused by epoxy coating are described. Tests include beam-end specimens containing No. 5, No. 6, No. 8, and No. 11 (16, 19, 25, and 36 $\mathrm{mm})$ bars. Bottom-cast and top-cast bars with 1, 2, or 3 bar diameters of cover are evaluated. Concrete slump ranges from $2 \frac{1}{4}$ to 8 in. (55 to 205 $\mathrm{mm}$ ). Some specimens containing high slump concrete are not vibrated. The results of the study are used to develop improved development length modification factors for epoxy-coated bars.

Epoxy coatings significantly reduce bond strength. However, the extent of the reduction is less than used to select the development length modification factors in the 1989 ACI Building Code and the 1989 AASHTO Bridge Specifications for bars with cover $<3$ bar diameters $\left(\mathrm{d}_{\mathrm{b}}\right)$ or a clear spacing $<6 \mathrm{~d}_{\mathrm{b}}$. The development length modification factor can be reduced from 1.5 to 1.35 for these bars. The relative bond strength of epoxy-coated reinforcement increases as cover increases. As a result, the development length modification factor of 1.2 in ACI 318-89 is realistic for epoxy-coated bars with a cover $\geq 3 \mathrm{~d}_{\mathrm{b}}$ and a clear spacing $\geq 6 \mathrm{~d}_{\mathrm{b}}$ when combined with the 0.8 factor for bars with a clear spacing $\geq 5 \mathrm{~d}_{\mathrm{b}}(A C I)$ or a center-to-center spacing $\geq 6$ in. (AASHTO). However, the modification factor of 1.15 in the 1989 AASHTO Bridge Specifications is slightly unconservative for these bars and should be modified. The ratio of the bond strength of bottom-cast bars to the bond strength of top-cast bars, $\mathrm{B} / \mathrm{T}$, is about the same for coated and uncoated bars cast in low slump concrete. $\mathrm{B} / \mathrm{T}$ increases significantly for uncoated bars and decreases slightly for coated bars as slump increases. As a result, the upper limit on the product of the epoxy-coating factor and the top-bar factor can be reduced from 1.7 to 1.5. A lack of vibration has a negative effect on the bond strength of both coated and uncoated reinforcement in high slump concrete.

This is the third in a series of papers describing research at the University of Kansas on epoxy-coated reinforcement. The research is aimed at gaining a better understanding of the bond of epoxy-coated reinforcement to concrete and developing design procedures that accurately reflect the changes in bond strength caused by epoxy coating.

Keywords: bond (reinforcement to concrete); coatings; deformed reinforcement; epoxy-coated reinforcement; pullout tests; reinforcing steels; structural engineering.

The development length provisions of the 1989 ACI Building Code (ACI 318-89) and the 1989 AASHTO Bridge Specifications require the use of considerably longer development lengths for epoxy-coated reinforcement than for uncoated steel. Under these provisions, a development length modification factor of 1.5 is required for coated bars with less than three bar diameters of concrete cover or less than six bar diameters of clear spacing. The provisions also reflect the belief that (1) the detrimental effects of epoxy coating on bond will decrease with increased cover and bar spacing and (2) the detrimental effects of epoxy-coating and bar position are not fully additive for top bars [bars with more than 12 in. $(305 \mathrm{~mm})$ of concrete cast below the bar]. Thus, factors of 1.2 (ACI 1989) or 1.15 (AASHTO 1989) are used for bars with 3 bar diameters or more concrete cover and 6 bar diameters or more of clear spacing between bars, and although top-bar factors of 1.3 (ACI 1989) and 1.4 (AASHTO 1989) are applied for all top bars, an upper limit of 1.7 is placed on the product of the epoxy-bar and top-bar factors.

The current provisions are based on tests of 21 splice specimens, 12 of which contained epoxy-coated reinforcement, by Treece and Jirsa $(1987,1989)$ and their interpretation of tests of eight beam-end specimens with confined reinforcement by Johnston and Zia (1982).* Although limited in scope, the study by Treece and Jirsa $(1987,1989)$ provided experimental justification for a 1.5 factor for epoxy-coated bars with low cover and spacing. There are, however, no specific experimental data in either study to support the lower factor (1.2 or 1.15) based on higher cover and spacing or the limit of 1.7 on the product of the epoxy-bar and top-bar factors. Subsequent work at the University of Kansas (Choi et al. 1990a, 1990b, 1991; Hadje-Ghaffari et al. 1991; Hester et al. 1991, 1993) and Purdue University (Cleary and Ramirez 1989,1991 ) indicates that, while epoxy coating significantly reduces bond strength, the reduction is less than reflected by the development length modification factors in ACI 318-89 and the AASHTO Bridge Specifications (1989). Specifically, work by Choi et al. (1991) and Hester (1993), which includes *Johnston and Zia (1982) tested 26 beam-end specimens under static loading.
However, most of the tests were terminated without a bond failure, at bond forces about 125 percent of yield. Only two groups of four specimens each provided data based on bond stength. From these tests, Johnston and Zia recommended that the development lengths of epoxy-coated bars be increased by 15 percent. Treece and Jirsa $(1987,1989)$ interpreted this recommendation as applying to "bars with large cover or wide spacing where splitting is unlikely." However, all eight specimens exhibited splitting cracks.

ACI Structural Journal, V. 91, No. 1, January-February 1994.

Received July 7, 1992, and reviewed under Institute publication policies. Copyright (C) 1994, American Concrete Institute. All rights reserved, including the making of copies unless permission is obtained from the copyright proprietors. Pertinent discussion will be published in the November-December 1994 ACI Structural Journal if received by be published $1,1994$.
July 1,190 
ACI member Hossain Hadje-Ghaffari is an assistant professor at Sharif University of Technology and a civil engineer and architect with IRAN SALOYD Architects, Planners and Engineers in Tehran, Iran. He holds a B.S. degree in architectural studies from the University of Nebraska at Lincoln and M.S. and Ph.D. degrees in civil engineering from the University of Kansas.

ACI member Oan Chul Choi is an assistant professor of architectural engineering at Soong Sil University in Seoul, Korea. He obtained B.S. and M.S. degrees from Seoul National University and his Ph.D. from the University of Kansas. He has served as a structural engineer at Hyundai Construction Co., Seoul, and previously taught at Ulsan University in Korea. His research interests include the experimental study of bond and the finite element analysis of reinforced concrete.

David Darwin, FACI, is the Deane E. Ackers Professor of Civil Engineering and Director of the Structural Engineering and Materials Laboratory at the University of Kansas. He is a past member of the Board of Direction and the Technical Activities Committee and is Past-President of the Kansas Chapter of ACI. Darwin is Chairman of the Publications Committee and the Concrete Research Council and is a member and past-chairman of ACI Committee 224, Cracking. He is also a member of ACI Committees 408, Bond and Development of Reinforcement, 446, Fracture Mechanics, and ACI-ASCE Committees 445, Shear and Torsion, and 447, Finite Element Analysis of Reinforced Concrete Structures.

ACI member Steven L. McCabe is an associate professor of civil engineering at the University of Kansas. He is active in research involving reinforced concrete, structural analysis/design for dynamic loading, and finite element techniques. McCabe is PastPresident of the Kansas Chapter of ACI, Chairman of ACI Committee 439, Steel Reinforcement, and a member of ACI Committees 408, Bond and Development of Reinforcement, and 446, Fracture Mechanics, and ACI-ASCE Committee 447, Finite Element Analysis of Reinforced Concrete Structures.
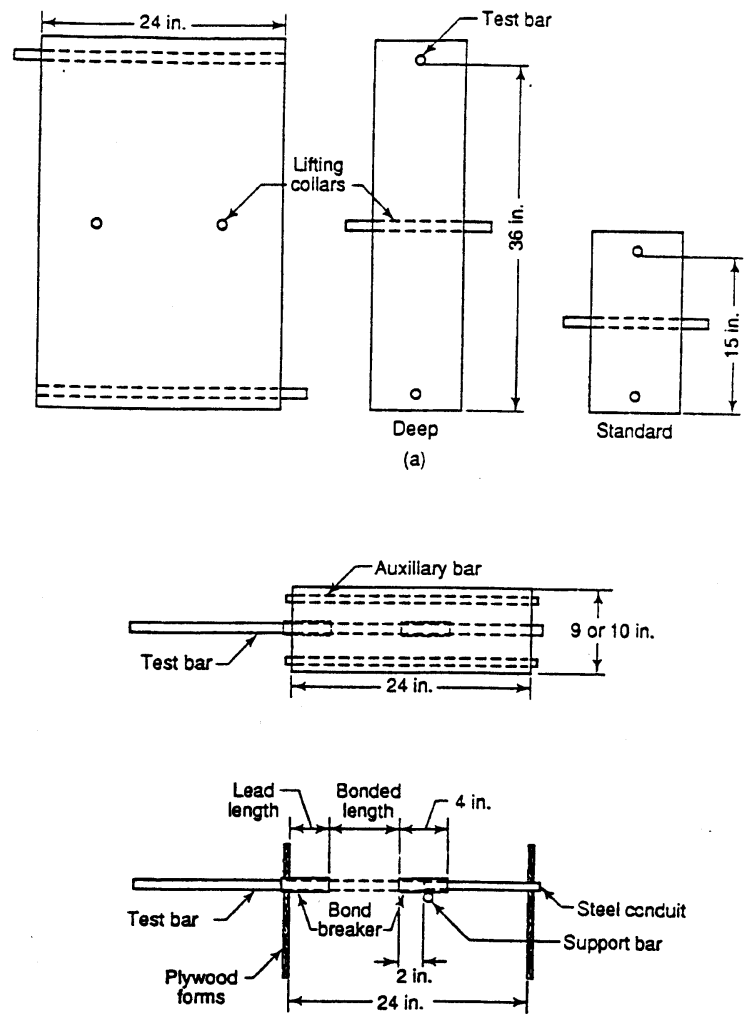

(b)

Fig. 1-(a) Beam-end specimen dimensions; (b) test-bar installation $(1 \mathrm{in} .=25.4 \mathrm{~mm})$

analysis of the work by Treece and Jirsa $(1987,1989)$, as well as more recent work by Hamid, Jirsa, and d'Abreu de Paulo (1990), indicates that a basic development length modification factor of 1.35 is satisfactory for coated bars (with or without transverse reinforcement) with less than three bar diameters and clear spacing between bars less than six bar diameters.
This paper, the third in a continuing series describing research at the University of Kansas, describes research to characterize the effects of cover, casting position (top or bottom-cast bars), slump, and degree of consolidation on the bond strength of epoxy-coated reinforcement. Earlier papers in the series (Choi et al. 1991; Hester et al. 1993) have dealt with the effects of coating thickness, deformation pattern, bar size, and transverse reinforcement on the development and splice strength of deformed reinforcing bars. Additional details on the tests presented in this paper are available in Choi et al. (1990b) and Hadje-Ghaffari et al. (1991, 1992).

\section{RESEARCH SIGNIFICANCE}

Epoxy-coated reinforcing bars are used in concrete structures where corrosion protection is a principal design requirement. The bars exhibit a lower bond strength to concrete than uncoated bars. Considering the increasing application of epoxy-coated reinforcement, the conservatism of current design provisions, and the limited data upon which those provisions are based, an improved understanding of the bond behavior is warranted. The goal is to improve economy and constructability while maintaining an adequate margin of safety. The current study is of special significance because it presents, for the first time, specific experimental evidence on the effects of bar casting position and increased cover on the reduction in bond strength caused by epoxy coating.

\section{EXPERIMENTAL PROGRAM}

The overall experimental program (Choi et al. 1990b, 1991; Hadje-Ghaffari et al. 1991, 1992; Hester et al. 1993) involved 637 beam-end specimens and 85 full-scale splice specimens. This paper presents the results obtained from 376 beam-end specimens used to evaluate the effects of cover, casting position, slump, and consolidation. The tests involve No. 5, No. 6, No. 8 , and No. $11(16,19,25$, and $36 \mathrm{~mm})$ bars with three deformation patterns.

\section{Test specimens}

Beam-end specimens containing No. 5, No. 6, and No. 8 bars were $9 \mathrm{in} .(229 \mathrm{~mm})$ wide $\mathrm{x} 24 \mathrm{in}$. $(610 \mathrm{~mm})$ long (Fig. 1). The width was increased to $10 \mathrm{in}$. $(254 \mathrm{~mm})$ for specimens containing No. 11 bars. Most of the tests used specimens with 15 in. (381 $\mathrm{mm}$ ) of concrete above or below the bars for bottom-cast and top-cast bars, respectively, and 1,2, or 3 bar diameters of cover. Selected tests used deep specimens with $36 \mathrm{in}$. of concrete below top-cast or above bottom-cast bars for No. 8 bars (Fig. 1). Specimen dimensions were based on the work of Brettmann, Darwin, and Donahey $(1984,1986)$.

Test bars extended 22 in. $(560 \mathrm{~mm})$ out from the face of the specimens. Two polyvinyl chloride (PVC) pipes were used as bond breakers to control the bonded length of the bar and to avoid a localized cone-type failure of the concrete at the loaded end of the specimen (Brettmann, Darwin, and Donahey 1984, 1986). Bonded lengths (length of test bars in contact with concrete) of $3 \frac{1}{2}, 4 \frac{1}{2}, 8$, and 9 in. $(89,114$, 203 , and $229 \mathrm{~mm}$ ) were used for No. 5, No. 6, No. 8, and No. 11 bars, respectively. The corresponding lengths of bond breaking PVC pipe in front of the bars (lead lengths) were $2 \frac{3}{8}, 23 / 4,3 \frac{3}{4}$, and $1 \frac{1}{2}$ in. $(60,70,95$, and $38 \mathrm{~mm})$, respec- 


\begin{tabular}{c|c|c|c|c|c|c|c|c|c|c}
\hline Bar size & $\begin{array}{c}\text { Deformation } \\
\text { pattern }\end{array}$ & $\begin{array}{c}\text { Yield } \\
\text { strength, ksi }\end{array}$ & $\begin{array}{c}\text { Deformation } \\
\text { height, * in. }\end{array}$ & $\begin{array}{c}\text { Deformation } \\
\text { spacing, in. }\end{array}$ & $\begin{array}{c}\text { Deformation } \\
\text { gap, in. }\end{array}$ & $\begin{array}{c}\text { Deformation } \\
\text { angle, deg }\end{array}$ & $\begin{array}{c}\text { Deformation } \\
\text { face angle, } \\
\text { deg }\end{array}$ & $\begin{array}{c}\text { Bearing } \\
\text { area/in., }{ }^{\dagger} \text { in. }\end{array}$ & $\begin{array}{c}\text { Related rib } \\
\text { area }^{\ddagger}\end{array}$ & $\begin{array}{c}\text { Bearing area } \\
\text { ratio, in. }{ }^{-1}\end{array}$ \\
\hline 5 & $\mathrm{~S}$ & 70.6 & 0.031 & 0.423 & 0.159 & 90 & 47 & 0.112 & 0.057 & 0.361 \\
5 & $\mathrm{C}$ & 72.3 & 0.040 & 0.413 & 0.140 & 60 & 45 & 0.146 & 0.074 & 0.471 \\
5 & $\mathrm{~N}$ & 68.4 & 0.041 & 0.379 & 0.158 & 70 & 51 & 0.169 & 0.086 & 0.545 \\
\hline 6 & $\mathrm{~S}$ & 63.8 & 0.040 & 0.502 & 0.154 & 90 & 45 & 0.141 & 0.060 & 0.320 \\
6 & $\mathrm{C}$ & 70.9 & 0.047 & 0.467 & 0.122 & 60 & 57 & 0.185 & 0.079 & 0.420 \\
6 & $\mathrm{~N}$ & 64.2 & 0.051 & 0.462 & 0.151 & 70 & 49 & 0.197 & 0.084 & 0.448 \\
\hline 8 & $\mathrm{~S}$ & 67.0 & 0.053 & 0.674 & 0.176 & 90 & 50 & 0.202 & 0.064 & 0.256 \\
8 & $\mathrm{C}$ & $* *$ & 0.062 & 0.656 & 0.195 & 60 & 56 & 0.241 & 0.077 & 0.305 \\
8 & $\mathrm{~N}$ & 63.8 & 0.057 & 0.602 & 0.160 & 70 & 55 & 0.250 & 0.080 & 0.316 \\
\hline 11 & $\mathrm{~S}$ & 64.6 & 0.076 & 0.945 & 0.217 & 90 & 55 & 0.315 & 0.071 & 0.202 \\
11 & $\mathrm{C}$ & 63.1 & 0.074 & 0.840 & 0.196 & 60 & 45 & 0.306 & 0.069 & 0.196 \\
11 & $\mathrm{~N}$ & 64.3 & 0.077 & 0.914 & 0.195 & 70 & 43 & 0.289 & 0.065 & 0.185 \\
\hline
\end{tabular}

*Per ASTM A 615.

Bearing area of the deformations divided by the space between deformations. Bearing area based on closely spaced measurements of ribs.

${ }^{\ddagger}$ Ratio of bearing area of deformations to shearing area between deformations (bearing area per in. divided by nominal perimeter of bar).

${ }^{\S}$ Ratio of bearing area of deformations to area of bar (bearing area per in. divided by nominal area of bar).

**Yield strength is greater than $70 \mathrm{ksi}$.

Bar sizes: No. $5=16 \mathrm{~mm}$; No. $6=19 \mathrm{~mm}$; No. $8=25 \mathrm{~mm}$; No. $11=36 \mathrm{~mm}$.

1 in. $=25.4 \mathrm{~mm} ; 1 \mathrm{ksi}=6.89 \mathrm{MPa}$.

tively. Two auxiliary bars, parallel to the test bar, were used to prevent the specimen from failing in flexure (Fig. 1). The size of the auxiliary bars depended on the test-bar size. No. $4(13 \mathrm{~mm})$ auxiliary bars were used for No. 5 and No. 6 test bars. No. 5 and No. 6 auxiliary bars were used for No. 8 and No. 11 bars, respectively.

\section{Materials}

Reinforcing steel-ASTM A 615 (1987) Grade 60 (414 MPa) No. 5 , No. 6, No. 8, and No. 11 bars were used. Bars with three deformation patterns, designated S, C, and N, were tested (see Choi et al. 1991). Deformation pattern $S$ consists of ribs perpendicular to the axis of the bar. Deformation pattern C consists of ribs inclined at $60 \mathrm{deg}$ with respect to the axis of the bar. Deformation pattern $\mathrm{N}$ consists of ribs inclined at $70 \mathrm{deg}$ with respect to the axis of the bar. Bars of each size and deformation pattern were from the same heat of steel. Yield strengths and deformation properties are shown in Table 1 . The bearing areas and face angles of the deformations were determined using methods presented by Choi et al. (1990b) and Hadje-Ghaffari et al. (1991). The epoxy-coating was commercially applied in accordance with ASTM A 775 (1988).

Concrete-Non-air entrained concrete was supplied by a local ready-mix plant. Type I portland cement, 3/4 in. (19 $\mathrm{mm}$ ) nominal maximum size crushed limestone, and Kansas River sand were used. A high-range water-reducer was added to some mixes to obtain a high slump. Water-cement ratios ranging from 0.55 to 0.41 were used to obtain concrete with nominal strengths of 5000 and 6000 psi (34 and $41 \mathrm{MPa})$. $6000 \mathrm{psi}(41 \mathrm{MPa})$ was used for the majority of the specimens.

\footnotetext{
* The appendixes are available in xerographic or similar form from ACI headquarters, where they will be kept permanently on file, at a charge equal to the cost of reproduction plus handling at time of request.
}

ACI Structural Journal / January-February 1994
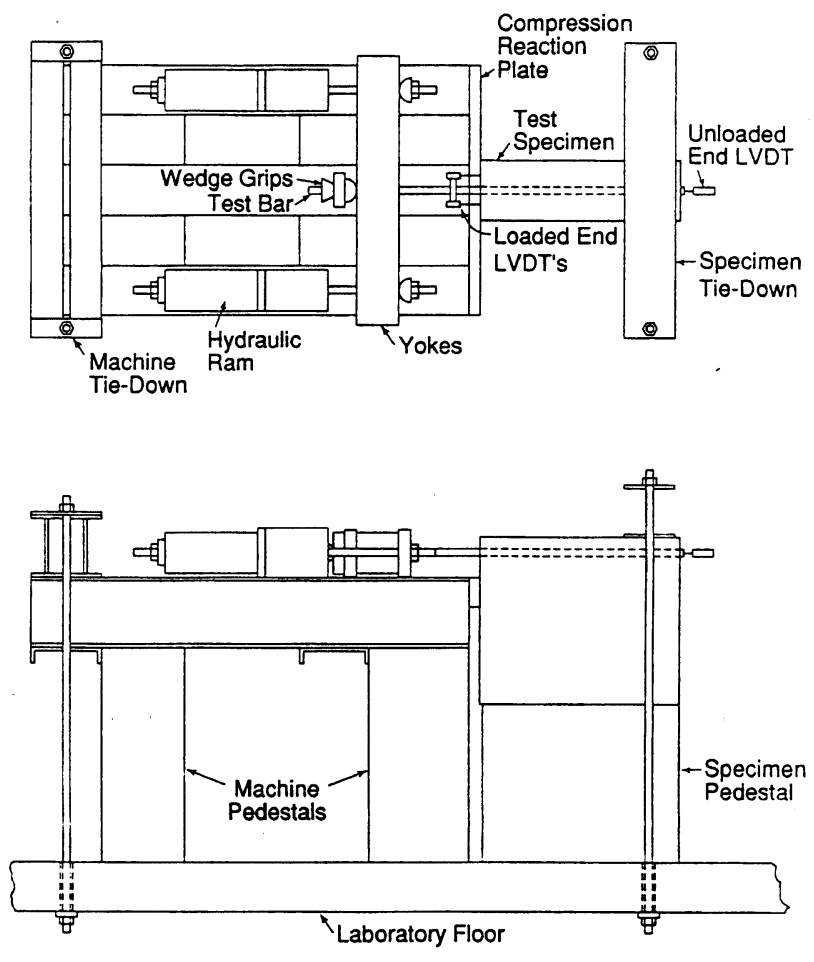

Fig. 2-Schematic of test apparatus

Mix proportions and concrete properties for individual specimen groups are presented in Appendix A.*

\section{Test procedure}

Tests were made at nominal concrete strengths of 5000 or $6000 \mathrm{psi}$ (34 and $41 \mathrm{MPa}$ ). Flexural bond strength was measured using an apparatus developed by Donahey and Darwin 
(1983, 1985) and modified by Brettmann, Darwin, and Donahey $(1984,1986)$ (Fig. 2). Specimens containing No. 5 and No. 6 bars were loaded at about 3.0 kips $(13.3 \mathrm{kN})$ per min, while specimens containing No. 8 and No. 11 bars were tested at about 6.0 kips $(26.7 \mathrm{kN})$ per min (Brettmann, Darwin, and Donahey 1984, 1986; Choi et al. 1990b).

\section{Results and observations}

Details of load-slip behavior are provided by Choi et al. (1990a, 1990b, 1991) and Hadje-Ghaffari et al. (1991). Overall, uncoated bars provided higher bond strengths than coated bars. At a given load, coated bars exhibited greater slip than uncoated bars, and in most cases coated bars failed at greater values of slip than uncoated bars.

As observed in earlier studies (Johnston and Zia 1982; Treece and Jirsa 1987, 1989; Choi et al. 1990a, 1990b, 1991, Hester et al. 1991), after failure, concrete exhibited good adhesion to uncoated bars and virtually no adhesion to epoxy-coated bars. The test variables (bar size and pattern, coating thickness, concrete strength) and ultimate bond forces of the bars are listed in Appendix B.

\section{EVALUATION OF EXPERIMENTAL RESULTS}

This report emphasizes the role of bar placement and construction procedures on the bond strength of epoxy-coated reinforcement. Specifically, the roles of cover, casting position, concrete slump, and degree of consolidation are studied. The effect of epoxy-coating on bond strength is evaluated by calculating the ratio of the bond strength of coated bars to the bond strength of uncoated bars $C / U$.

To compare the individual tests on an equitable basis, the ultimate bond strengths are corrected for variations in concrete strength by normalizing the test results with respect to a nominal concrete strength of $6000 \mathrm{psi}$ (41 MPa), using the assumption that, within the concrete strength range used, bond strength is proportional to the square root of the compressive strength. Thus, bond strengths are multiplied by $\left(6000 / f_{c}^{\prime}\right)^{1 / 2}\left[\left(41 / / f_{c}^{\prime}\right)^{1 / 2}\right]$. The resulting normalized ultimate bond forces are plotted in Fig. 3 through 8.

For data reported in tabular form, the normalized bond strengths of individual specimens are also corrected for variations in the actual cover from nominal values of 1,2 , and 3 bar diameters $\left(d_{b}\right)$. As described by Choi et al. (1991), this adjustment is obtained by plotting normalized bond strengths for bars of a given size versus the actual cover, for covers ranging from 1 to $3 d_{b}$. As shown in Fig. 3, 4, and 5, best fit lines for different groups of specimens are nearly parallel, independent of deformation pattern or bar surface condition (coated or uncoated). Using the technique of dummy variables (Draper and Smith 1981), parallel best fit lines are obtained based on the assumption that changes in cover cause the same incremental change in bond strength for bars of the same size, independent of deformation pattern or test group. Thus, each group of specimens is represented by a separate line. Individual specimen strengths are corrected by shifting the measured bond strength parallel to the best fit lines to a value corresponding to the nominal cover $\left(1,2\right.$, or $\left.3 d_{b}\right)$. A similar correction should be made for the effects of variations in epoxy-coating thickness. However, work by Choi et al. (1990a, 1990b, 1991) shows that, of the bars tested in this study, only No. 5 bars are sensitive to coating thickness. Thus, modifications for coating thickness [9 mils $(0.23 \mathrm{~mm})$ taken as the standard] are made only for No. 5 bars (HadjeGhaffari et al. 1991).

\section{Concrete cover}

Cover affects the confinement provided to reinforcing bars. Its effect on the normalized ultimate bond forces for No. 5, No. 8, and No. 11 bars is shown in Fig. 3, 4, and 5, respectively. These figures show that, regardless of bar position, bar size, or deformation pattern, there is a nearly linear increase in bond force with increasing concrete cover. The best fit lines for coated and uncoated bars are nearly parallel, but the absolute magnitude of the increase in bond strength with cover is slightly greater for uncoated bars than for coated bars.

As a result of the relationships illustrated in Fig. 3 through $5, C / U$ increases as cover increases. These trends are illustrated for bars with covers of $2 d_{b}$ and more in Table 2 , which provides a summary of the $C / U$ ratios for No. 5 , No. 8 , and No. 11 bars from test groups that had specimens with different covers. Values of $C / U$ provided in the tables are based on both the best fit lines illustrated in Fig. 3 through 5 and the average strengths for bars of each deformation pattern at each nominal value of cover. With the exception to the top-cast S-pattern No. 8 bars, the values of $C / U$ based on average strengths (AV) exhibit a greater increase with cover than do the values of $C / U$ based on the best fit lines (BF). For example, $C / U$ based on the best-fit lines for bottom-cast N-pattern No. 8 bars, increases from 0.89 to 0.91 as the concrete cover increases from two to three bar diameters, while $C / U$ based on the average strengths increases from 0.87 to 0.94 .

Table 3 summarizes the $U / C$ ratios (inverse of $C / U$ ratios in Table 2) for bars with different covers in beam-end specimens, as a function of bar size, along with the current ACI (1989) and AASHTO (1989) modification factors for epoxycoated bars. Table 3 shows that the largest value of $U / C$ for bars with a cover of $3 d_{b}, 1.22$ for No. 11 bars (based on the best fit line), is in agreement with the current ACI development length factor, 1.2, for epoxy-coated bars with $\geq 3 d_{b}$ of cover. The highest value of $\mathrm{U} / \mathrm{C}$ for bars with a $3 d_{b}$ cover based on the average of actual test results is only 1.16 (also for No. 11 bars). For No. 5 and No. 8 bars, the highest U/C ratio for bars with a $3 d_{b}$ cover is 1.10 , based on best fit lines (top-cast S-pattern and N-pattern No. 8 bars and bottom-cast N-pattern No. 8 bars), and 1.14, based on average of actual test results (top-cast $S$-pattern No. 8 bars). These results suggest that the ACI 1.2 factor might be reduced slightly for No. 8 and smaller bars.

A picture of the combined effects of epoxy coating and cover on bond strength is provided in Table 2 using the term $C^{\prime} / U$, the ratio of the bond strength of coated bars with $3 d_{b}$ cover to the bond strength of uncoated bars with $2 d_{b}$ cover. The $C^{\prime} / U$ ratios in Table 2 are, without exception, greater than 1.0, i.e., coated bars with $3 d_{b}$ cover, consistently exhibit greater bond strength than uncoated bars with $2 d_{b}$ cover. Thus, the combined effects of the higher $C / U$ ratio and improved bond strength with increased cover overcome the reduced bond strength caused by epoxy coating. The implication for design is that no increase in 


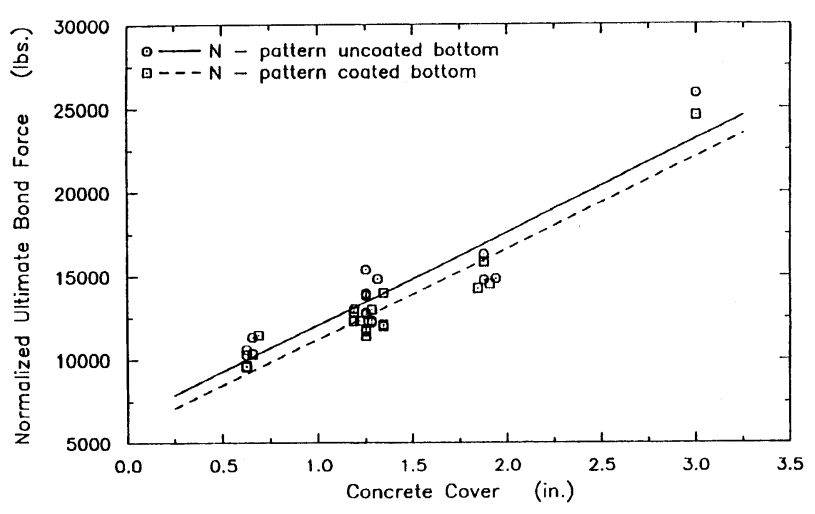

Fig. 3-Normalized ultimate bond force versus concrete cover for No. 5 bars $(1 \mathrm{lb}=4.45 \mathrm{kN} ; 1 \mathrm{in} .=25.4 \mathrm{~mm})$

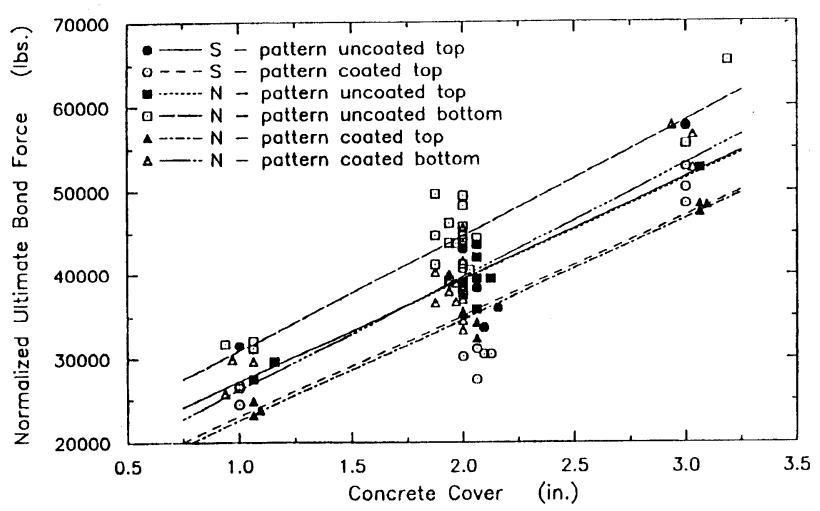

Fig. 4-Normalized ultimate bond force versus concrete cover for No. 8 bars $(1 \mathrm{lb}=4.45 \mathrm{kN} ; 1 \mathrm{in} .=25.4 \mathrm{~mm})$

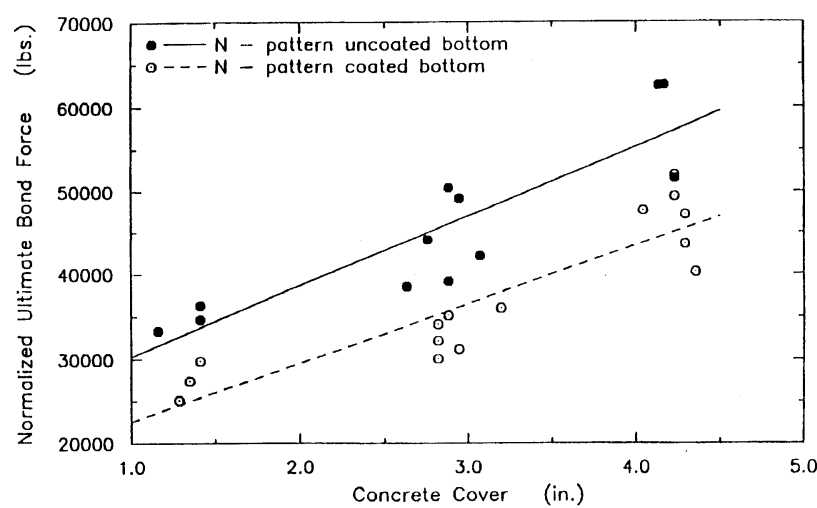

Fig. 5-Normalized ultimate bond force versus concrete cover for No. 11 bars $(1 \mathrm{lb}=4.45 \mathrm{kN} ; 1 \mathrm{in} .=25.4 \mathrm{~mm})$

development length is needed for coated bars with covers $\geq 3 d_{b}$, if the beneficial effect of cover $>2 d_{b}$ is not already considered for uncoated bars.

Neither the 1989 ACI Building Code nor the 1989 AASHTO Bridge Specifications take advantage of the added bond strength provided by cover $>2 d_{b}$ for uncoated bars. However, the beneficial effect of increased spacing is considered for both uncoated and coated bars in ACI 318-89 and the 1989 AASHTO Bridge Specifications ( 0.8 factor for bars with clear spacing $\geq$ $5 d_{b}$ or center-to-center spacing $\geq 6$ in., respectively), and it is

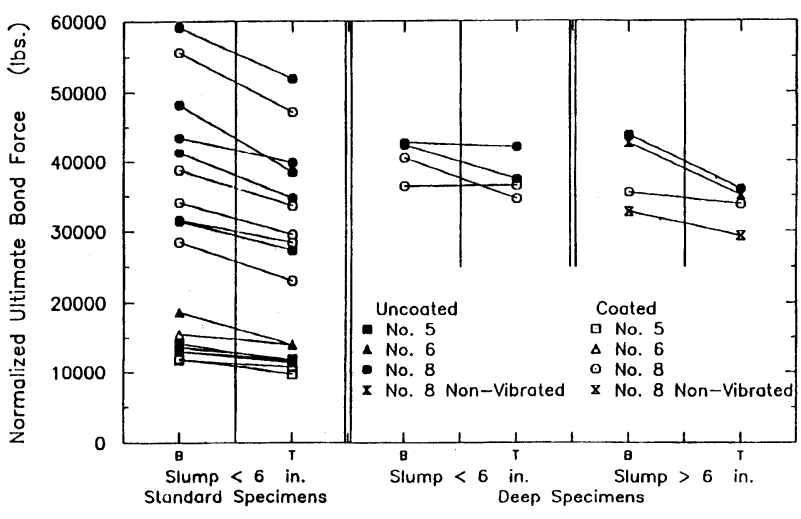

Fig. 6-Normalized ultimate bond force for bottom and topcast bars for different slump concretes in standard and deep specimens $(1 \mathrm{lb}=4.45 \mathrm{kN} ; 1 \mathrm{in} .=25.4 \mathrm{~mm})$

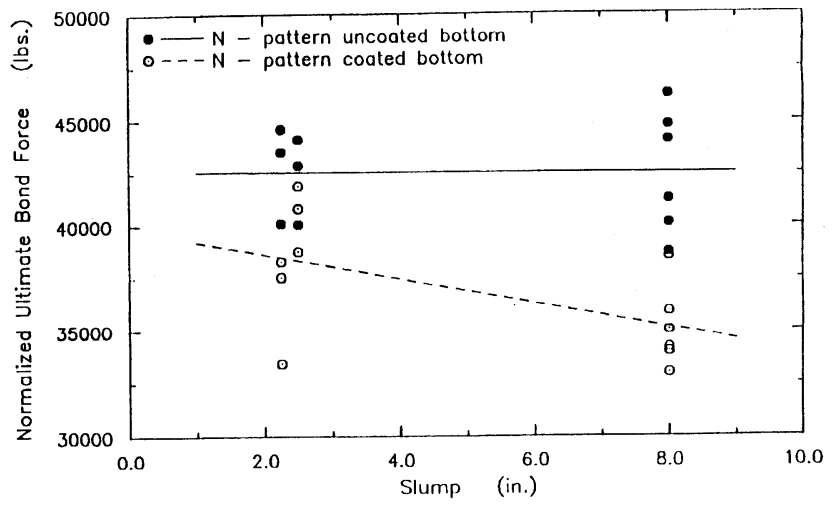

Fig. 7-Normalized ultimate bond force for bottom-cast bars versus slump for No. 8 bars in deep specimens $(1 \mathrm{lb}=4.45$ $k N ; 1$ in. $=25.4 \mathrm{~mm}$ )

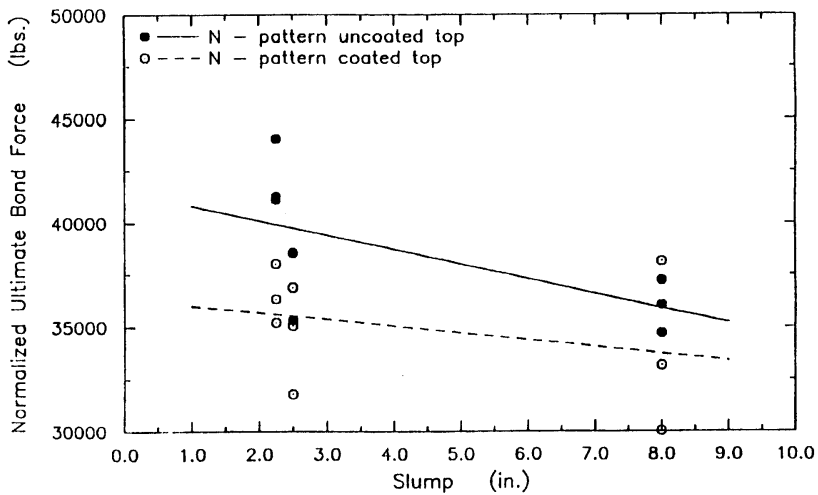

Fig. 8-Normalized ultimate bond force for top-cast bars versus slump for No. 8 bars in deep specimens $(1 \mathrm{lb}=4.45$ $k N ; 1$ in. $=25.4 \mathrm{~mm}$ )

well established (Orangun, Jirsa, and Breen 1977) that bond strength is controlled by the smaller of the cover $C_{b}$, or one-half of the clear spacing between bars $C_{s}$ (if $\mathrm{C}_{s}<C_{b}, C_{s}$ plays the role of cover in governing bond strength). Thus, for bars with covers $\geq 3 d_{b}$ and clear spacings $\geq 6 d_{b}$, the development length modification factor for epoxy-coated bars can be lowered to 1.0 only if the 0.8 factor for wide spacing is not applied for coated bars. If the 0.8 factor is retained for coated as well as uncoated bars, the 1.2 factor (ACI 318-89) for epoxy-coated bars with cover $\geq 3 d_{b}$ and clear spacing $\geq 6 \mathrm{~d}_{\mathrm{b}}(0.8 \times 1.2=0.96)$ should 
Table 2-Relative bond strengths, $C / U$ and $C^{\prime} / U$, versus bar size and concrete cover

\begin{tabular}{|c|c|c|c|c|c|c|c|c|}
\hline \multirow{2}{*}{ Bar size } & \multirow{2}{*}{$\begin{array}{c}\text { Deformation } \\
\text { pattern }\end{array}$} & \multirow[b]{2}{*}{ Group no. } & \multirow{2}{*}{$\begin{array}{l}\text { Casting } \\
\text { position* }\end{array}$} & \multirow[b]{2}{*}{ Cover, $d b^{*}$} & \multicolumn{2}{|c|}{$C / U^{\dagger}$} & \multicolumn{2}{|c|}{$C^{\prime} / U^{\ddagger}$} \\
\hline & & & & & $B F^{*}$ & $A V^{*}$ & $B F^{*}$ & $A V^{*}$ \\
\hline \multirow[t]{3}{*}{5} & $\mathrm{~N}$ & $8,11-13$ & B & 2 & 0.93 & 0.91 & & \\
\hline & & 13 & & 3 & 0.94 & 0.98 & 1.19 & 1.11 \\
\hline & & 13 & & 4.8 & 0.95 & 0.97 & & \\
\hline \multirow[t]{6}{*}{8} & $S$ & $1,15,18$ & $\mathrm{~T}$ & 2 & 0.89 & 0.89 & & \\
\hline & & 1 & & 3 & 0.91 & 0.88 & 1.19 & 1.37 \\
\hline & $\mathrm{N}$ & $4,6,15,18,23,24$ & B & 2 & 0.89 & 0.87 & & \\
\hline & & 18 & & 3 & 0.91 & 0.94 & 1.19 & 1.25 \\
\hline & $\mathrm{N}$ & 15,18 & $\mathrm{~T}$ & 2 & 0.88 & 0.86 & & \\
\hline & & 18 & & 3 & 0.91 & 0.91 & 1.19 & 1.21 \\
\hline \multirow[t]{2}{*}{11} & $\mathrm{~N}$ & 19,20 & B & 2 & 0.79 & 0.74 & & \\
\hline & & 19,20 & & 3 & 0.82 & 0.86 & 1.03 & 1.07 \\
\hline
\end{tabular}

$d_{b}=$ bar diameter.

$B F=$ based on best-fit line.

$A V=$ based on average test data.

${ }^{\dagger}$ Ratio of bond stength of coated bar to bond strength of uncoated bar with same cover.

${ }^{\ddagger}$ Ratio of bond stength of coated bar to bond strength of uncoated bar with $1 d_{b}$ less than cover.

Table 3-Comparison of experimental and design epoxy-coated bar development length modification factors

\begin{tabular}{|c|c|c|c|c|c|c|c|}
\hline \multirow[b]{2}{*}{ Bar size } & \multirow{2}{*}{$\begin{array}{c}\text { Deformation } \\
\text { pattern }\end{array}$} & \multirow{2}{*}{$\begin{array}{l}\text { Casting } \\
\text { position* }\end{array}$} & \multirow[b]{2}{*}{ Cover, $d_{b} *$} & \multicolumn{2}{|c|}{ Experimental $U / C^{\dagger}$} & \multicolumn{2}{|c|}{ Design $U / C^{\ddagger}$} \\
\hline & & & & $B F^{*}$ & $A V^{*}$ & $\mathrm{ACI}$ & AASHTO \\
\hline \multirow[t]{3}{*}{5} & \multirow[t]{3}{*}{$\mathrm{N}$} & \multirow[t]{3}{*}{ B } & 2 & 1.07 & 1.10 & 1.5 & 1.5 \\
\hline & & & 3 & 1.06 & 1.02 & 1.2 & 1.15 \\
\hline & & & 4.8 & 1.05 & 1.03 & 1.2 & 1.15 \\
\hline \multirow[t]{6}{*}{8} & \multirow[t]{2}{*}{$S$} & \multirow[t]{2}{*}{$\mathrm{T}$} & 2 & 1.12 & 1.12 & 1.5 & 1.5 \\
\hline & & & 3 & 1.10 & 1.14 & 1.2 & 1.15 \\
\hline & \multirow[t]{2}{*}{$\mathrm{N}$} & \multirow[t]{2}{*}{ B } & 2 & 1.12 & 1.15 & 1.5 & 1.5 \\
\hline & & & 3 & 1.10 & 1.06 & 1.2 & 1.15 \\
\hline & \multirow[t]{2}{*}{$\mathrm{N}$} & \multirow[t]{2}{*}{$\mathrm{T}$} & 2 & 1.14 & 1.16 & 1.5 & 1.5 \\
\hline & & & 3 & 1.10 & 1.10 & 1.2 & 1.55 \\
\hline \multirow[t]{2}{*}{11} & \multirow[t]{2}{*}{$\mathrm{N}$} & \multirow[t]{2}{*}{ B } & 2 & 1.26 & 1.35 & 1.5 & 1.5 \\
\hline & & & 3 & 1.22 & 1.16 & 1.2 & 1.15 \\
\hline
\end{tabular}

*Casting position: $\mathbf{B}=$ bottom-cast $\mathbf{T}=$ top-cast.

$d_{b}=$ bar diameter.

$B F=$ based on best-fit line

$A V=$ based on average test data.

${ }^{\dagger}$ Ratio of bond strength of uncoated bar to bond strength of coated bar .

${ }^{\ddagger}$ Development length modification factor (ACI 1989; AASHTO 1989).

also be retained. This combination of factors corresponds to a $C^{\prime} / U$ ratio of 1.04 , which is justified by the results illustrated in Table 2.

The combination of the 0.8 factor with the AASHTO (1989) factor of 1.15 for epoxy-coated bars with cover $\geq 3$ $d_{b}$ and clear spacings $\geq 6 d_{b}(0.8 \times 1.15=0.92)$ corresponds to a $C^{\prime} / U$ ratio of $1 / 0.92=1.09$, which is justified for No. 8 and smaller bars (Table 2) but is slightly unconservative for No. 11 bars $\left(C^{\prime} / U=1.03-1.07\right)$.

\section{Casting position, concrete slump, and consolidation}

The casting position of a bar affects its bond strength. The greater the amount of concrete cast below a bar, the greater the effects of settlement and bleeding and the lower the bond strength. The ACI Building Code (1989) and the AASHTO
Bridge Specifications (1989) recognize these effects for "top bars" by increasing the required development lengths by 30 and 40 percent, respectively, for reinforcement with more than 12 in. $(305 \mathrm{~mm})$ of concrete cast below the bar. Luke et al. (1981) and Brettmann, Darwin, and Donahey (1984, 1986) demonstrated that the top-bar effect is greatest for "top-cast" bars, i.e., bars cast near the upper surface of a placement, and that this effect increases as concrete slump increases. Brettmann et al. $(1984,1986)$ also demonstrated that the bond strength of bars in high slump concrete is reduced if the concrete is not vibrated. Thus, concrete slump and consolidation, as well as casting position, play a role in the "top-bar" effect.

The effects of casting position (top or bottom-cast), concrete slump, and degree of consolidation (vibration) of plastic concrete for bars in the current study are shown in Fig. 6,

ACI Structural Journal / January-February 1994 
Table 4-Average bond strengths and bond-strength ratios for bottom and top-cast bars in standard and deep specimens with different slump concretes and degrees of consolidation

\begin{tabular}{|c|c|c|c|c|c|c|c|c|c|c|c|c|c|}
\hline \multirow[b]{2}{*}{ Bar size } & \multirow[b]{2}{*}{ Group no. } & \multirow[b]{2}{*}{$\begin{array}{c}\text { Deforma- } \\
\text { tion } \\
\text { pattern }\end{array}$} & \multirow[b]{2}{*}{ Slump, in. } & \multirow[b]{2}{*}{ Cover, $d_{b}$} & \multirow{2}{*}{$\begin{array}{c}\text { No. of } \\
\text { uncoated } \\
\text { bars }\end{array}$} & \multirow{2}{*}{$\begin{array}{c}\text { Uncoated } \\
\text { bars: } \\
\text { normalized } \\
\text { bond } \\
\text { strength, } \\
\text { lb }\end{array}$} & \multirow[b]{2}{*}{$\begin{array}{c}\text { No. of } \\
\text { coated } \\
\text { bars }\end{array}$} & \multirow{2}{*}{$\begin{array}{c}\text { Coated } \\
\text { bars: } \\
\text { normalized } \\
\text { bond } \\
\text { strength, } \\
\text { lb }\end{array}$} & \multirow{2}{*}{$C P^{*}$} & \multicolumn{3}{|c|}{$B / T^{*}$} & \multirow[b]{2}{*}{$\begin{array}{l}C / U^{*} \\
\text { group }\end{array}$} \\
\hline & & & & & & & & & & $U / U^{*}$ & $C / C^{*}$ & $U_{b} / C_{t}{ }^{*}$ & \\
\hline \multirow[t]{2}{*}{5} & \multirow[t]{2}{*}{9} & \multirow[t]{2}{*}{$\mathrm{S}$} & \multirow[t]{2}{*}{4} & \multirow[t]{2}{*}{2} & 3 & 14,154 & 6 & 11,753 & B & \multirow[t]{2}{*}{1.228} & \multirow[t]{2}{*}{1.097} & \multirow[t]{2}{*}{1.321} & 0.830 \\
\hline & & & & & 3 & 11,522 & 6 & 10,714 & $\mathrm{~T}$ & & & & 0.930 \\
\hline \multirow[t]{2}{*}{5} & \multirow[t]{2}{*}{10} & \multirow[t]{2}{*}{$\mathrm{C}$} & $4 \frac{1}{2}$ & 2 & 3 & 13,580 & 6 & 13,010 & B & 1.138 & 1.144 & 1.194 & 0.958 \\
\hline & & & & & 3 & 11,932 & 6 & 11,375 & $\mathrm{~T}$ & & & & 0.953 \\
\hline 5 & 11 & $\mathrm{~N}$ & $31 / 4$ & 2 & 3 & 12,964 & 3 & 11,998 & B & 1.105 & 1.238 & 1.338 & 0.925 \\
\hline & & & & & 3 & 11,732 & 3 & 9688 & $\mathrm{~T}$ & & & & 0.826 \\
\hline & & & & 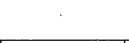 & & & & verage of $\mathrm{N}$ & 5 bars $=$ & 1.157 & 1.160 & 1.284 & \\
\hline 6 & 17 & $\mathrm{~S}$ & $5 \frac{3}{4}$ & 2 & 3 & 18,720 & 6 & 15,525 & B & 1.340 & 1.114 & 1.343 & 0.829 \\
\hline & & & & & 3 & 13,973 & 2 & 13,941 & $T$ & & & & 0.998 \\
\hline & & & & & & & & verage of $\mathrm{No}$ & 6 bars $=$ & 1.340 & 1.114 & 1.343 & \\
\hline 8 & 5 & $\mathrm{~N}$ & $4 \frac{1}{4}$ & 2 & 3 & 43,464 & - & - & B & 1.091 & - & - & - \\
\hline & & & & & 3 & 39,832 & - & - & $\mathrm{T}$ & & & & - \\
\hline 8 & 15 & $S$ & $4 \frac{1 / 4}{4}$ & 2 & 2 & 42,680 & 6 & 31,600 & B & - & 1.112 & 1.502 & 0.740 \\
\hline & & & & & - & - & 2 & 28,416 & $\mathrm{~T}$ & & & & \\
\hline 8 & 18 & $\mathrm{~N}$ & $41 / 4$ & 1 & 3 & 31,424 & 3 & 28,520 & B & 1.149 & 1.238 & 1.364 & 0.908 \\
\hline & & & & & 3 & 27,352 & 3 & 23,040 & $\mathrm{~T}$ & & & & 0.842 \\
\hline 8 & 18 & $\mathrm{~N}$ & $41 / 4$ & 2 & 3 & 48,256 & 3 & 38,800 & B & 1.256 & 1.155 & 1.437 & 0.804 \\
\hline & & & & & 3 & 38,432 & 3 & 33,592 & $\mathrm{~T}$ & & & & 0.874 \\
\hline 8 & 18 & $\mathrm{~N}$ & $41 / 4$ & 3 & 2 & 59,160 & 3 & 55,696 & B & 1.139 & 1.180 & 1.254 & 0.941 \\
\hline & & & & & 1 & 51,960 & 3 & 47,192 & $\mathrm{~T}$ & & & & 0.908 \\
\hline 8 & 18 & $S$ & $41 / 4$ & 2 & 3 & 41,312 & 3 & 34,064 & B & 1.189 & 1.153 & 1.399 & 0.825 \\
\hline & & & & & 3 & 34,736 & 3 & 29,536 & $\mathrm{~T}$ & & & & 0.850 \\
\hline & & & & & & verage of $\mathrm{Nc}$ & 8 bars i & standard spe & imens = & 1.165 & 1.168 & 1.391 & \\
\hline $8^{\dagger}$ & 23 & $\mathrm{~N}$ & $2 \frac{1}{2}$ & 2 & 3 & 42,744 & 3 & 36,416 & B & 1.015 & 0.997 & 1.170 & 0.852 \\
\hline & & & & & 3 & 42,120 & 3 & 36,520 & $\mathrm{~T}$ & & & & 0.867 \\
\hline $8^{\dagger}$ & 24 & $\mathrm{~N}$ & $2 \frac{1}{2}$ & 2 & 3 & 42,360 & 3 & 40,488 & B & 1.131 & 1.170 & 1.225 & 0.956 \\
\hline & & & & & 3 & 37,464 & 3 & 34,592 & $\mathrm{~T}$ & & & & 0.923 \\
\hline & & & & Average $o$ & f No. 8 bars & $\mathrm{rs}$ in deep sp & cimens & low-slump v & rated $)=$ & 1.073 & 1.084 & 1.198 & \\
\hline $8^{\dagger}$ & 24 & $\mathrm{~N}$ & 8 & 2 & 3 & 43,848 & 3 & 35,504 & B & 1.218 & 1.051 & 1.298 & 0.810 \\
\hline & & & & & 3 & 36,008 & 3 & 33,776 & $\mathrm{~T}$ & & & & 0.938 \\
\hline & & & & Average of & No. 8 bars & $\mathrm{s}$ in deep spe & cimens & iigh-slump v & rated) $=$ & 1.218 & 1.051 & 1.298 & \\
\hline $8^{\dagger, \ddagger}$ & 24 & $\mathrm{~N}$ & 8 & 2 & 3 & 42,656 & 3 & 32,752 & B & 1.216 & 1.116 & 1.454 & 0.768 \\
\hline & & & & & 3 & 35,080 & 3 & 29,344 & $T$ & & & & 0.836 \\
\hline & & & & Average of & No. 8 bars & in deep spec & mens (hi & h-slump non & brated) & 1.216 & 1.116 & 1.454 & \\
\hline & & Average & of No. $8 \mathrm{ba}$ & $\mathrm{rs}$ in deep sp & ecimens $=$ & & & & & 1.145 & 1.084 & 1.287 & \\
\hline & & & Aver & age of all $\mathrm{N}$ & 0.8 bars $=$ & & & & & 1.156 & 1.130 & 1.345 & \\
\hline & & & AVERA & GE OF AL & L BARS $=$ & & & & & 1.170 & 1.136 & 1.331 & \\
\hline
\end{tabular}

${ }^{*} C P=$ casting position $-B=$ bottom-cast $T=$ top-cast .

$B / T=$ ratio, bottom-cast bars to top-cast bars; $U / U=$ ratio, uncoated bottom-cast bars to uncoated top-cast bars; $C / C=$ ratio, coated bottom-cast bars to coated top-cast bars; $U_{b} / C_{t}$ $=$ ratio, uncoated bottom-cast bars to coated top-cast bars; $\mathrm{C} / \mathrm{U}=$ ratio, coated bars to uncoated bars.

Bar sizes: No. $5=16 \mathrm{~mm}$; No. $6=19 \mathrm{~mm}$; No. $8=25 \mathrm{~mm}$.

† Deep specimens.

${ }^{\ddagger}$ Nonvibrated specimens.

$1 \mathrm{in}$. $=25.4 \mathrm{~mm} ; 1 \mathrm{lb}=4.45 \mathrm{kN}$.

which provides a summary of normalized ultimate bond strengths obtained from standard beam-end specimens with slumps below 6 in. $(150 \mathrm{~mm})$ and deep beam-end specimens with slumps both below and above 6 in. $(150 \mathrm{~mm})$. Of the 52 data points shown, 48 represent the average of at least three tests. Some of the specimens made with high slump concrete were vibrated and some were not. The effects of casting position are also illustrated in Fig. 4.

For the tests illustrated, top-cast bars exhibit a lower bond strength than the corresponding bottom-cast bars, and bars cast in high slump concrete exhibit a reduced bond strength if the concrete is not vibrated. The top-cast bars in high slump 
Table 5-Summary of hypothesis testing for average bond strength ratios

\begin{tabular}{|c|c|c|c|c|c|c|c|c|c|c|c|c|c|c|c|}
\hline \multirow{3}{*}{ Bar size } & \multirow{3}{*}{$\begin{array}{c}\text { Slump, } \\
\text { in. }\end{array}$} & \multirow{3}{*}{$\begin{array}{l}\text { Consoli- } \\
\text { dation* }\end{array}$} & \multirow{3}{*}{$\begin{array}{c}\text { Specimen } \\
\text { type }^{\dagger}\end{array}$} & \multicolumn{5}{|c|}{ Bottom/Top $(B / T)$} & \multicolumn{5}{|c|}{ Coated/Uncoated $(C / U)$} & \multirow{2}{*}{\multicolumn{2}{|c|}{$\mathrm{U}_{b} / C_{t}^{* *}$}} \\
\hline & & & & \multicolumn{2}{|c|}{ Uncoated } & \multicolumn{2}{|c|}{ Coated } & \multirow{2}{*}{$\begin{array}{c}\mathrm{U} \text { and } \mathrm{C}^{\ddagger} \\
\mathrm{H} \text { test }\end{array}$} & \multicolumn{2}{|c|}{ Bottom } & \multicolumn{2}{|c|}{ Top } & \multirow{2}{*}{$\begin{array}{c}B \text { and } T^{\S} \\
\mathrm{H} \text { test }\end{array}$} & & \\
\hline & & & & ratio & $\mathrm{H}$ test* & ratio & $\mathrm{H}$ test* & & ratio & $\mathrm{H}$ test* & ratio & $\mathrm{H}$ test* & & ratio & $\mathrm{H}$ test* \\
\hline 5 & $3 \frac{1}{1 / 4-4}{ }^{1 / 2}$ & $\mathrm{v}$ & ST & 1.157 & $S$ & 1.160 & $S$ & NS & 0.904 & $S$ & 0.903 & $S$ & NS & 1.284 & $S$ \\
\hline 8 & $4 \frac{1}{2}$ & $\mathrm{~V}$ & ST & 1.165 & $S$ & 1.168 & $S$ & NS & 0.870 & $S$ & 0.869 & $S$ & NS & 1.391 & $S$ \\
\hline 8 & $2 \frac{1}{4}-2^{1} / 2$ & $\mathrm{~V}$ & $\mathrm{D}$ & 1.073 & $S$ & 1.084 & $S$ & NS & 0.904 & $S$ & 0.895 & $S$ & NS & 1.200 & $S$ \\
\hline \multicolumn{4}{|c|}{ Average-low slump } & 1.132 & & 1.137 & & & 0.893 & & 0.889 & & & 1.292 & \\
\hline 6 & $53 / 4$ & $\mathrm{~V}$ & ST & 1.340 & $S$ & 1.114 & $S$ & $S$ & 0.829 & $S$ & 0.998 & NS & $S$ & 1.343 & $S$ \\
\hline 8 & 8 & $\mathrm{~V}$ & $\mathrm{D}$ & 1.218 & $\mathrm{~S}$ & 1.051 & NS & $\mathrm{S}$ & 0.810 & $S$ & 0.938 & NS & $\mathrm{S}$ & 1.298 & $\mathrm{~S}$ \\
\hline \multicolumn{4}{|c|}{ Average-high-slump vibrated } & 1.279 & & 1.083 & & & 0.820 & $S$ & 0.968 & & & 1.321 & \\
\hline 8 & 8 & NV & $\mathrm{D}$ & 1.216 & $S$ & 1.116 & $S$ & $S$ & 0.768 & $S$ & 0.836 & $\mathrm{~S}$ & $S$ & 1.454 & $S$ \\
\hline
\end{tabular}

*Consolidation: $\mathrm{V}=$ vibrated; $\mathrm{NV}=$ not vibrated.

$\mathrm{H}$ test-results of hypothesis testing: $\mathrm{S}=$ difference in bond strengths indicated by ratio is statistically significant with a confidence of 97.5 percent; NS = difference in bond strengths indicated by ratio is not statistically significant with a confidence of 97.5 percent.

Specimen type: $\mathrm{ST}=$ standard; $\mathrm{D}=$ deep.

${ }^{\ddagger}$ Hypothesis test for difference in $B / T$ for uncoated and coated bars.

$\S$ Hypothesis test for difference in $C / U$ for bottom and top bars.

**Bond strength ratio: uncoated bottom-cast bars to coated top-cast bars.

1 in. $=25.4 \mathrm{~mm}$.

concrete, whether vibrated or not, have a lower bond strength than the top-cast bars in lower slump concrete.

Casting position and concrete slump-The effects of casting position and slump on bond strength are illustrated in Fig. 7 and 8 for deep beam-end specimens containing N-pattern No. 8 bars. In Fig. 7 and 8, normalized bond strengths are plotted versus concrete slump for vibrated bottom and top-cast $\mathrm{N}$-pattern No. 8 bars (groups 23 and 24), respectively. These figures show that, with the exception of the bottom-cast uncoated bars, the ultimate bond strength decreased with increased slump.

The ratio of bottom to top-cast bar bond strength $(B / T)$ is commonly referred to as the "top-bar effect." For the results illustrated in Fig. 7 and 8 (deep specimens), uncoated and coated bars cast in low slump concrete exhibit similar top-bar effects, with $\mathrm{B} / \mathrm{T} \cong 1.07$. As expected (Menzel 1952; Luke et al. 1981; Brettmann, Darwin, and Donahey 1984, 1986), the top-bar effect increases for uncoated bars (to about 1.2) as the concrete slump increases to $8 \mathrm{in}$. $(205 \mathrm{~mm})$. However, the top-bar effect is virtually constant for coated bars (about 1.04) as slump increases, showing that the top-bar effect is lower for coated bars than for uncoated bars.

A more detailed look at the interaction between coating and the top-bar effect is provided by Tables 4 and 5 . Table 4 summarizes the normalized bond strengths, and $C / U$ and $B / T$ ratios for all groups containing specimens with both topand bottom-cast bars (Groups 9 through 11, 15, 17, 18, 23, and 24). In all but one case (coated No. 8 bars in Group 23), bottom-cast bars are stronger in bond than the companion top-cast bars. For the one exception, $B / T=1.00$.

In Table 5, the $B / T$ and $C / U$ ratios from Table 4 are averaged based on bar size and concrete slump. In addition, the average $B / T$ ratios for uncoated and coated bars, the average $C / U$ ratios for bottom and top-cast bars, and the average uncoated $\left(U_{b}\right)$ bottom-cast to coated $\left(C_{t}\right)$ top-cast bar bond strength ratios $\left(U_{b} / C_{t}\right)$ for all bars and concrete slumps are statistically analyzed, using the technique of hypothesis testing (Harnett 1975), to see if the differences in bond strengths represented by these ratios are statistically significant [for example, in the case of No. 6 bars, does the average $B / T$ ratio for uncoated bars, 1.34 , represent a significant difference in bond strength (due to the top-bar effect) or is the value of $B / T$ due to the scatter in the data? And is the difference between the $B / T$ ratios for uncoated bars, 1.34 , and coated bars, 1.11 , significant (due to the coating) or is it not significant (due to scatter in the data)?].

The hypothesis testing summarized in Table 5 indicates that, with at least a 97.5 percent level of confidence (probability of making an error in the determination $\leq 2.5$ percent), the differences obtained in the bond tests as represented by $B / T$ and $C / U$ are statistically significant (not due to scatter), with the exception of the $B / T$ ratio for No. 8 coated bars in vibrated high slump concrete (1.05) and the $C / U$ ratios for No. $6(1.00)$ and No. 8 (0.94) top-cast bars in vibrated high slump concrete.

Table 5 also shows that for low slump concrete [slump $\leq 5 \mathrm{in}$. $(130 \mathrm{~mm})]$, the values of $B / T$ are virtually the same for uncoated and coated bars for both standard and deep specimens. The average $B / T$ ratios for low slump concrete are 1.13 and 1.14 (actually 1.132 and 1.137) for uncoated and coated bars, respectively. Also for low slump concrete, the average $C / U$ ratios are virtually the same, at 0.89 , for bottom- and top-cast bars, respectively.

For high-slump concrete [slump $>5 \mathrm{in}$. $(130 \mathrm{~mm})$ ], however, the $B / T$ ratios are significantly different for uncoated and coated bars. The average $B / T$ ratio in high-slump concrete is 1.28 for uncoated bars compared to 1.08 for coated bars. This reduction in the top-bar effect can be attributed to the fact that the epoxy coating and the weakened concrete at the interface caused by bleeding and settlement have similar, nonadditive effects on bond strength. Thus, while the average $B / T$ ratio for uncoated bars increases from 1.13 to 1.28 as slump increases, the average $B / T$ ratio for coated bars decreases from 1.14 to 1.08. It follows from these observations that $C / U$ is significantly different for bottom and top-cast bars in high slump concrete. The average value of $C / U$ for bars in vibrated high slump concrete is 0.82 for bottom-cast bars, compared to 0.97 for top-cast bars. In fact, with increased slump, $C / U$ decreases, from 0.89 to 0.82 , for bottom-cast bars but increases, from 0.89 to 0.97 , for top-cast bars.

The trends observed for $B / T$ are important because the value of the top-bar development length modification factor used in the ACI Building Code (1989), 1.3, is based on a worst case assumption, i.e., bars cast in high-slump concrete. 
The average $B / T$ obtained in the current study for uncoated bars cast in high-slump concrete, 1.28, agrees well with the ACI factor. Since coated bars do not appear to be affected as greatly as uncoated bars at higher slumps, it can be argued that a top-bar factor below 1.3 can be used for epoxy-coated bars. The results in Table 5 indicate that a value close to 1.14 (the average value of $B / T$ for coated bars in low-slump concrete) would be appropriate. This value compares favorably with the defacto top-bar factor for epoxy-coated bars in ACI $318-89,1.13$, which is obtained by dividing the upper limit on the combined effects of bar position and epoxy coating, 1.7 , by the epoxy-bar factor, 1.5. Rounding up slightly gives a factor of 1.15 for epoxy-coated top bars.

The values of $U_{b} / C_{t}$, ratio of uncoated bottom-cast bar strength to coated top-cast bar strength, in Tables 4 and 5 show the combined effects of coating and bar position on the bond strength of coated top bars. Average $U_{b} / C_{t}$ ratios of $1.29,1.32$ and 1.45 (Table 5) for low-slump, high-slump vibrated, and high-slump nonvibrated concrete, respectively, demonstrate that the ACI upper limit on the combined factors, 1.7, can be conservatively decreased to 1.5 for coated top bars.

Overall, it appears that a top-bar factor of 1.15 for coated bars, applied to the development length of bottom-cast coated bars and/or an upper limit of 1.5 on the combined factors, applied to the development length of bottom-cast uncoated bars, will provide safe, satisfactory designs.

Consolidation-As shown in Fig. 6 and Table 4 (Group 24 ), the lack of vibration has a negative effect on bond strength in high slump concrete, regardless of casting position, for both coated and uncoated bars. In the case illustrated in Fig. 6, a lack of vibration of the 8 in. slump concrete caused normalized bond strengths to drop by 2.7 and 2.6 percent (Table 4 ) for uncoated bottom and top-cast bars, respectively. The differences were greater for coated bars, where a lack of vibration caused reductions of 9.2 and 13.1 percent for bottom and top-cast bars, respectively.

As seen in Table 4 for the bars in Group 24, $B / T$ remains nearly constant (about 1.22) for uncoated bars but rises from 1.05 to 1.16 for coated bars when the concrete is not vibrated. In addition, $C / U$ drops from 0.81 to 0.77 for bottom-cast bars and from 0.94 to 0.84 for top-cast bars when the concrete is not vibrated. Thus, a lack of vibration appears to be more detrimental for coated bars than for uncoated bars. As observed for vibrated high slump concrete, $C / U$ for bars in nonvibrated high slump concrete is higher for top-cast bars, 0.84 , than for bottom-cast bars, 0.77 .

\section{DESIGN RECOMMENDATIONS}

This study points the way to a number of modifications in the development length provisions for epoxy-coated bars in the ACI Building Code (1989) and the AASHTO Bridge Specifications (1989).

\section{Current provisions}

The current provisions consist of a 1.5 development length modification factor for epoxy-coated bars with a cover $<3$ $d_{b}$ or a clear spacing $<6 d_{b}$; a 1.2 (ACI) or 1.15 (AASHTO) modification factor for epoxy-coated bars with a cover $\geq 3$ $d_{b}$ and a clear spacing $\geq 6 d_{b}$; a top-bar factor of 1.3 (ACI) or 1.4 (AASHTO) for both coated and uncoated bars; and an upper limit of 1.7 on the product of the epoxy-coating factor and the top-bar factor. A factor of 0.8 can be used for all bars with a clear spacing $\geq 5 d_{b}(\mathrm{ACI})$ or a center-to-center spacing $\geq 6$ in. (AASHTO).

\section{Proposed provisions}

As shown here and in an earlier work by Choi et al. (1990a, 1990b, 1991) and Hester et al. (1991), the development-length modification factor of 1.5 for epoxy-coated bars with a cover $<3 d_{b}$ or a clear spacing $<6 d_{b}$ can be reduced to 1.35.

For epoxy-coated bars with a cover $\geq 3 d_{b}$ and a clear spacing $\geq 6 d_{b}$, the study shows that a development length modification factor of 1.0 could be used, but only if the 0.8 factor for widely spaced bars is not. If the 0.8 factor is retained, the current ACI (1989) epoxy-coating factor of 1.2 should be retained for bars with cover $\geq 3 d_{b}$ and clear spacing $\geq 6 d_{b}$, and the 1.15 factor used by AASHTO (1989) should be increased to 1.2 .

The relative insensitivity of coated bars to the top-bar effect, especially when high slump concrete is used, strongly supports a reduction in the development length modification factor for coated top bars from 1.3 to 1.15 and a reduction in the upper limit on product of the epoxy-coating factor and the top-bar factor from 1.7 to 1.5 . While both steps are justified, an upper limit on the combined factors would be easier to apply than different top-bar factors for coated and uncoated bars.

\section{SUMMARY AND CONCLUSIONS}

This study continues earlier research (Choi et al. 1991, Hester et al. 1993) on the bond strength of epoxy-coated reinforcement to concrete. The current effort evaluates the effect of concrete cover, casting position, slump, and degree of consolidation on the bond strength of epoxy-coated reinforcement using beam-end specimens containing No. 5, No. 6, No. 8, and No. 11 bars. Bottom-cast and top-cast bars with one, two, or three bar diameters of cover were evaluated. Concrete slump ranged from $2 \frac{1}{4} 4$ to 8 in. (55 to $205 \mathrm{~mm}$ ), and some specimens containing high-slump concrete were not vibrated.

Based on the tests and evaluations presented in this report, it may be concluded that:

1. Epoxy coating reduces the bond strength of reinforcing steel to concrete. However, for bars with a cover $<3 d_{b}$ or a clear spacing $<6 d_{b}$, the extent of the reduction is less than that used to establish the development length modification factors in the 1989 ACI Building Code and the 1989 AASHTO Bridge Specifications.

2. The bond strength of both coated and uncoated bars increases as cover increases, regardless of casting position, bar size, or deformation pattern. The absolute value of the increase is approximately the same for coated and uncoated bars, resulting in an increase in the relative bond strength of coated bars, $\mathrm{C} / \mathrm{U}$, with increasing cover.

3 . The average bond strength of coated bars with $3 d_{b}$ cover exceeds the average bond strength of uncoated bars with 2 $d_{b}$ cover. As a result, the current provisions of the 1989 ACI Building Code are realistic as they are applied to epoxycoated bars with a cover $\geq 3 \mathrm{~d}_{\mathrm{b}}$ and a clear spacing $\geq 6 \mathrm{~d}_{\mathrm{b}}$. 
The provisions of the 1989 AASHTO Bridge Specifications are somewhat unconservative for these bars and should be modified.

4. As the depth of concrete below a bar increases, the bond strength decreases, regardless of bar size, deformation pattern, or bar surface condition.

5. Bars cast in low slump concrete are stronger in bond than bars cast in high slump concrete of the same compressive strength.

6. The ratio of the bond strength of bottom-cast bars to the bond strength of top-cast bars, $B / T$, (a measure of the top-bar effect) increases significantly for uncoated bars and decreases slightly for coated bars as slump increases.

7. In low slump concrete, $B / T$ is about the same for uncoated and coated bars, and $C / U$ is about the same for bottom and top-cast bars.

8. In high slump concrete that is adequately vibrated, $B / T$ is lower for coated bars than for uncoated bars, and $C / U$ is greater for top-cast bars than for bottom cast bars.

9. For coated bars, the relative insensitivity of $B / T$ to increasing slump allows the use of a reduced top-bar factor for epoxy-coated bars and/or a decrease in the upper limit of the product of the epoxy-bar factor and the top-bar factor.

10. Lack of vibration of high slump concrete has a negative effect on the bond strength of all bars, coated and uncoated, bottom and top-cast. Lack of vibration is more detrimental for coated bars than for uncoated bars.

\section{ACKNOWLEDGMENTS}

Major funding for this research was provided by the National Science Foundation under Grant No. ECE-8616228. Reinforcing steel was supplied by Chaparral Steel Company, North Star Steel Company, Sheffield Steel Corporation, and Structural Metals, Inc. The epoxy coating was applied by ABC Coating Company, Inc. and Simcote, Inc.

\section{REFERENCES}

AASHTO Highway Sub-Committee on Bridges and Structures, 1989. Standard Specifications for Highway Bridges, 14th Edition, American Association of State Highway and Transportation Officials, Washington, DC, $420 \mathrm{pp}$.

ACI Committee 318, 1989. "Building Code Requirements for Reinforced Concrete and Commentary (ACI 318-89/ACI 318R-89)," American Concrete Institute, Detroit, 353 pp.

ASTM, 1987. "Standard Specification for Deformed and Plain BilletSteel Bars for Concrete Reinforcement," (ASTM A 615-87a) 1989 Annual Book for ASTM Standards, Vol. 1.04, American Society for Testing and Materials, Philadelphia, pp. 381-384.

ASTM, 1988. "Standard Specification for Epoxy-Coated Reinforcing Steel Bars," (ASTM A 775/A775M-88a) 1989 Annual Book for ASTM Standards, Vol. 1.04, American Society for Testing and Materials, Philadelphia, pp. 548-552.

Brettmann, Barrie B; Darwin, David; and Donahey, Rex C., 1984. "Effect of Superplasticizers on Concrete-Steel Bond Strength," SL Report 84-1, University of Kansas Center for Research, Lawrence, Apr., 32 pp.

Brettmann, Barrie B; Darwin, David; and Donahey, Rex C., 1986. "Bond of Reinforcement to Superplasticized Concrete," ACI JourNaL, Proceedings Vol. 83, No. 1, Jan.-Feb., pp. 98-107.

Choi, Oan Chul; Hadje-Ghaffari, Hossain; Darwin, David; and McCabe, Steven L., 1990a. "Bond of Epoxy-Coated Reinforcement to Concrete: Bar
Parameters," SL Report 90-1, University of Kansas Center for Research, Lawrence, Jan., 43 pp.

Choi, Oan Chul; Darwin, David; and McCabe, Steven L., 1990b. "Bond Strength of Epoxy-Coated Reinforcement to Concrete," SM Report No. 25, Univ. of Kansas Center for Research, Lawrence, July, 217 pp.

Choi, Oan Chul; Hadje-Ghaffari, Hossain; Darwin, David; and McCabe, Steven L., 1991. "Bond of Epoxy-Coated Reinforcement: Bar Parameters," ACI Materials Journal, V. 88, No. 2, Mar.-Apr., pp. 207-217.

Cleary, Douglas B., and Ramirez, Julio A., 1989. "Bond of Epoxy Coated Reinforcing Steel in Concrete Bridge Decks," Joint Highway Research Project Information Report, JHRP 89-7, Purdue University, 127 pp.

Cleary, Douglas B., and Ramirez, Julio A., 1991. "Bond of Epoxy-Coated Reinforcement," ACI Materials Journal, V. 88, No. 2, Mar.-Apr., pp. 146149.

Donahey, Rex C., and Darwin, David, 1983. "Effects of Construction Procedures on Bond in Bridge Decks," SM Report No. 7, University of Kansas Center for Research, Lawrence, 129 pp.

Donahey, Rex C., and Darwin, David, 1985. "Bond of Top-Cast Bars in Bridge Decks, " ACI Journal, Proceedings V. 82, No. 1, Jan.-Feb., pp. 57-66.

Draper, N. R., and Smith, H., 1981. Applied Regression Analysis, Second Edition, John Wiley \& Sons, Inc., New York, pp. 241-249.

Hadje-Ghaffari, Hossain; Darwin, David; and McCabe, Steven L., 1991. "Effects of Epoxy Coating on Bond of Reinforcing Steel to Concrete," $S M$ Report No. 28, University of Kansas Center for Research, Lawrence, July, $288 \mathrm{pp}$.

Hadje-Ghaffari, Hossain; Choi, Oan Chul; Darwin, David; and McCabe, Steven L., 1992. "Bond of Epoxy-Coated Reinforcement to Concrete: Cover, Casting Position, Slump, and Consolidation," SL Report 92-3, Univ. of Kansas Center for Research, Lawrence, Kansas, June, 42 pp.

Hamid, Bilal S.; Jirsa, James O.; and d'Abreu de Paulo, Natalie I., 1990. "Effect of Epoxy Coating on Bond and Anchorage of Reinforcement in Concrete Structures, CTR Report 1181-1F, Center for Transportation Research, University of Texas at Austin, Dec., 242 pp.

Harnett, Donald L, 1975. Introduction to Statistical Methods, 2nd Ed. Addison-Wesley Publishing Co., pp. 263-301.

Hester, Cynthia J.; Salamizavaregh, Shahin; Darwin, David; and McCabe, Steven L., 1991. "Bond of Epoxy-Coated Reinforcement to Concrete: Splices," SL Report 91-1, University of Kansas Center for Research, Lawrence, Kansas, May, 66 pp.

Hester, Cynthia J.; Salamizavaregh, Shahin; Darwin, David; and McCabe, Steven L., 1993. "Bond of Epoxy-Coated Reinforcement: Splices," ACI Materials Journal, V. 90, No. 1, Jan.-Feb., pp. 89-102.

Johnston, David W., and Zia, Paul, 1982. "Bond Characteristics of Epoxy Coated Reinforcing Bars," Report No. FHWA-NC-82-002, Center for Transportation Engrg. Studies, Civil Engrg. Dept., North Carolina State University, Raleigh, $163 \mathrm{pp}$.

Luke, J. J.; Hamad, B. S.; Jirsa, J. O.; and Breen, J. E., 1981. "Influence of Casting Position on Development and Splice Length of Reinforcing Bars," Research Report No. 242-1, Center for Transportation Research, Bureau of Engineering Research, Univ. of Texas at Austin, June, 153 pp.

Menzel, Carl A., 1952. "Effects of Settlement of Concrete on Results of Pullout Tests," Research Department Bulletin 41, Research and Development Laboratories of the Portland Cement Association, Skokie, Nov., 49 pp.

Orangun, C. O.; Jirsa, J. O.; and Breen, J. E., 1977. "Reevaluation of Test Data on Development Length and Splices," ACI Journal, Proceedings V. 74, No. 3, Mar., pp. 114-122.

Treece, Robert A., and Jirsa, James O., 1987. "Bond Strength of EpoxyCoated Reinforcing Bars," PMFSEL Report No. 87-1, Phil M. Ferguson Structural Engineering Laboratory, University of Texas at Austin, Jan., 85 pp.

Treece, Robert A., and Jirsa, James O., 1989. "Bond Strength of EpoxyCoated Reinforcing Bars," ACI Materials Journal, V. 86, No. 2, Mar.-Apr., pp. 167-174. 